\title{
VARIATION IN AGES OF TRANSPLANTS AFFECTS AGRO- MORPHOLOGICAL TRAITS OF SELECTED PEPPER LANDRACES FROM NIGER STATE, NIGERIA
}

\author{
Oladipupo Abdulazeez Yusuf DAUDU ${ }^{1 *}$, Olamide Ahmed FALUSI ${ }^{1,2}$, \\ Abdulhakeem ABUBAKAR ${ }^{1}$, Aishatu Adamu GADO ${ }^{1}$, \\ Emmanuel Junior NWELIH ${ }^{1}$ \\ ${ }^{1}$ Department of Plant Biology, Federal University of Technology, Minna - Niger State \\ ${ }^{2}$ Ibrahim Babadamasi University, Lapai Niger State - Nigeria \\ *Corresponding author. E-mail: dauduoladipupoyusuf@yahoo.com
}

\begin{abstract}
Assessment of transplanting effects at different ages of seedling development on morphological and yield attributes in two landraces (SOMBO/MKW/2017 and NDAGBACHI/MKW/2017) of Nigerian pepper (Capsicum spp.) was studied during the planting season of 2017. The Capsicum landraces were obtained from local farmers in Mokwa, Niger State. The study was conducted at the experimental garden, Federal University of Technology, Minna, Niger State. Transplants were made at different ages (3, 4, 5 and 6 weeks after planting). The experimental design used was a Complete Randomized Design (CRD) with four replications of each treatment. Quantitative data obtained were pooled for analysis. Analysis of Variance (ANOVA) was used to compare the various mean values. Duncan Multiple Range Test (DMRT) post hoc test was used to separate the means. All values were considered significant at $\mathrm{p}<0.05$. The result showed some interesting variations among the different ages of transplants; the results of the plant height at maturity and number of leaves for NDAGBACHI/MKW/2017 revealed that week 3 had the highest plant height $(33.00 \mathrm{~cm})$ at maturity and also the highest number (39.50) of leaves. However, these values were not significantly different ( $>0.05$ ) from all other weeks. The results for plant height at harvest and number of branches revealed that week 4 recorded the highest height $(37.75 \mathrm{~cm})$ at harvest and highest number $(8.00)$ of branches, but is not statistically different $(\mathrm{p}>0.05)$ from other weeks. For SOMBO/MKW/2017, Week 4 recorded highest in terms of plant height $(30.08 \mathrm{~cm})$ at maturity, plant height $(32.50 \mathrm{~cm})$ at harvest and number of branches (9.25). These values were significantly different $(\mathrm{p}<0.05)$ from other weeks. For NDAGBACHI/MKW/2017, Week 3 produced the highest number of fruits/plant (28.00) but bears no significant difference (p>0.05) to all other weeks. However, for SOMBO/MKW/2017, Week 4 recorded the highest number of fruits/plant (35.00) and is significantly different $(\mathrm{p}<0.05)$ from week 3 and 6 but statistically the same with week 5 . In both landraces, Week 3 produced the highest number of seeds/fruit, but is statistically the same $(\mathrm{p}>0.05)$ with other weeks. It is therefore concluded that variation in transplanting age tend to influence certain morphological and yield attributes in Nigerian pepper landraces. Also, 3 and 4 week old transplants seem to be the best age to produce more yields for NDAGBACHI/MKW/2017 and SOMBO/MKW/2017 respectively. Further research works should be done to test for other higher ages at transplanting and also for different landraces in order to arrive at a sound conclusion.
\end{abstract}

Keywords: Capsicum, landraces, NDAGBACHI/MKW/2017, SOMBO/MKW/2017, transplanting, yield attributes.

\section{Introduction}

Pepper is an economically important crop belonging to the night shade family Solanaceae and genus Capsicum often divided into pungent and non-pungent, [PICKERSGILL, 1997]. Pepper originated from Central and South America where it is still being cultivated [GRUBBEN \& EL-TAHIR, 2004]. The genus consists of over 100 species and even more botanical varieties [FALUSI, 2007]. These include five domesticated 
species (Capsicum annuum, C. frutescens, C. chinense, C. pubescens and C. baccatum). C. annuum and $C$. frutescens are the most recognized species grown in commercial quantities all over Nigeria [FALUSI \& MORAKINYO, 2001; MADY \& al. 2005]. These two species form an important ingredient in people's diet around the world. The major center of diversity is Brazil, where representatives of all the species are found [COSTA \& al. 2009]. Despite being the center of origin and diversity of Capsicum species, little is known about the native species, particularly $C$. chinense Jacq., with great variability in the Amazon. They are considered the first spice used by humans and there is archaeological evidence of pepper and other fossil foods from as early as 6,000 years ago [HILL \& al. 2013]. Pepper was introduced to Europe by Columbus and other early new explorers in the sixteenth century and cultivation spreads throughout the world [GREENLEAF, 1986].

Pepper is an important commercial crop grown for vegetable spice and valueadded processed products [KUMAR \& RAI, 2005]. It is an essential component of many foods adding flavour, colour, vitamins $\mathrm{A}$ and $\mathrm{C}$ and pungency and it is therefore, indispensable to world food industries. It can be used medically for the treatment of fevers, colds, indigestion, constipation and also as painkiller [DAGNOKO \& al. 2013]. It is also used by security agencies to prepare tear gas. Peppers are an important source of nutrients in the human diet [SHETTY \& al. 2013], and it can be consumed fresh or dried. They promote health benefits such as reducing obesity and diabetes [VASCONCELOS, 2016]. Pepper extracts are used in cosmetics and pharmaceuticals. Besides the use in feed as spice, pepper has also ornamental potential when grown in pots or gardens [BOSLAND \& VOTAVA, 2012]. Proper age of transplanting, as an important cultural practice in pepper growing, is very important for maximum production of the crop.

Transplanting or indirect seedling is the process of growing seedlings in a greenhouse or other controlled environment before placing plants outdoors [AKINROTIMI \& ANIEKWE, 2018]. The effect of transplant age on yield is an issue often investigated by growers to maximize production potential [VAVRINA, 1998]. LIPTAY (1987) reported that moisture, which is essential for top growth of plants, is absorbed by root hairs. Such important roots hairs are destroyed during transplanting. The older the plant the more extensive its root system and the greater the root hairs lost in transplanting. NORMAN (1977) in his study on the effect of age of transplants on hot pepper remarked that flowering, fruiting and harvesting were delayed by transplanting and therefore recommended 5-6 weeks old transplants for hot pepper production in Ghana. When transplants are thought to be too old, concerns are raised about their subsequent growth and yield potential. Young transplants ( 3 to 4 weeks) reduce production costs, but will need to be grown longer in the field to reach optimum yields [LESKOVAR \& al. 1991; ORZOLEK \& al. 1991].

Research works done in other countries show that both growth and yield in pepper are markedly influenced by differentially aged seedlings and transplanting date. Cultural factors, such as transplant age [MCCRAW \& GREIG, 1986; WESTON, 1988], pruning [MCCRAW \& GREIG, 1986], fertility [SUNDSTROM \& al. 1994], influenced pepper yield. LEE \& al. (2001) reported that seedling growth of chilies was greater with increasing age of transplants. They concluded that plant height, dry weight and the number of branches increased with seedling age. It was based on this premise that this research was set up to evaluate the effect of various transplanting ages on the growth and yield of two landraces of pepper in Niger State, Nigeria and to determine the best transplanting age for this crop. 


\section{Materials and methods}

The Landraces of Capsicum annuum and C. frutescens were obtained from a local farmer in Kpaki, Mokwa Local Government area of Niger State. They were raised in planting trays before transplanting into planting bags at various weeks. Sixteen planting bags were obtained from Bida and labeled with the code of each landrace into which the corresponding landraces from the planting trays were transplanted. The experimental design used was a Complete Randomized Design (CRD) with four replications of each treatment. The ages of transplants were 3 weeks, 4 weeks, 5 weeks, and 6 weeks old after planting respectively. Seedlings were raised on well prepared nursery beds during the raining season of 2017. After sowing, the beds were watered. Transplanting was done early in the morning with four replicates of each landrace.

All the parameters investigated were assessed using the standard procedures of AKINYELE \& OSEKITA (2006) as well as DAUDU \& al. (2015) and AKINROTIMI \& ANIEKWE (2018). The following parameters were studied.Plant height were taken at transplanting, maturity (100\% flowering) and harvest; number of leaves and branches, number of leaves and branches of the two landraces was counted and the mean was recorded. Number of fruits/plant was obtained after the fruits harvested from the two landraces were counted from each treatment and the mean values recorded.Weight of fruits was done by random selection often fruits and each of them was weighed using an electronic weighing balance. Others include: number of seeds and Weight of 100 Seeds. Quantitative data obtained were pooled for analyses. Analysis of variance (ANOVA) was used to compare the various mean values. Duncan Multiple Range Post Hoc Test (DMRT) was used to separate the means. All values were considered significant at $95 \%$ confident level.

\section{Results and discussion}

The descriptive characteristics of the pepper landraces used in this study are presented in table 1; these include a hot chili (NDAGBACHI/MKW/2017) and long pepper with mild hotness (SOMBO/MKW/2017). The result obtained for the morphological parameters of NDAGBACHI/MKW/2017 is presented in table 2. The Analysis of Variance (ANOVA) showed that there is significant difference $(\mathrm{p}<0.05)$ for plant height at transplanting. The highest plant height $(6.50 \mathrm{~cm})$ was produced by Week 6 ; this value was significantly different $(\mathrm{p}<0.05)$ from all the other values. The lowest value $(4.05 \mathrm{~cm})$ was produced by Week 3 . However, the highest plant height at maturity $(33.00 \mathrm{~cm})$ was found in Week 3 while the lowest value $(23.13 \mathrm{~cm})$ was found in Week 4; these values were significantly different from each other. In terms of plant height at harvest, the results showed that there was no significant difference $(p>0.05)$ among the Weeks. The highest plant height $(37.75 \mathrm{~cm})$ was produced by Week 4 while the lowest plant height $(27.13 \mathrm{~cm})$ was produced by Week 6 . Similarly, this highest value was significantly different from each all the other weeks. For number of branches, the results showed that no significant difference existed ( $>0.05$ ) between transplants at week 3, 4 and 5; but the values were significantly different from that of week 6 after transplant (2.75). Week 4 recorded the highest number of branches (8.00) while which was followed by week 3 and 5 (5.25 each). There is no significant difference ( $>0.05)$ among week 3,4 and 5 after transplanting in terms of number of leaves. However, transplant at 3 week old had the highest number of 
leaves (39.50) while the lowest number of leaves (19.25) was produced by Week 6; these values were significantly different from each other.

The result obtained for the morphological parameters of SOMBO/MKW/2017 is also presented in table 2. There were significant differences $(\mathrm{p}<0.05)$ among the weeks in terms of plant height at transplanting. The highest plant height $(4.53 \mathrm{~cm})$ was found in Week 5; this value was statistically different $(\mathrm{p}<0.05)$ from all the other values. The lowest plant height $(3.80 \mathrm{~cm})$ was found in Week 3.

The highest plant height at maturity $(30.08 \mathrm{~cm})$ was recorded for Week 4 and lowest plant height $(8.38 \mathrm{~cm})$ was recorded from Week 6. For plant height at harvest, the results showed that there is no significant difference $(\mathrm{p}>0.05)$ in plants transplanted at week 3, 4 and 5. However, the highest plant height $(32.50 \mathrm{~cm})$ was found in Week 4 which was significantly different from the lowest $(21.00 \mathrm{~cm})$ obtained in Week 6 . In terms of number of branches per plant, the highest number of branches (9.25) was produced by Week 4 while the lowest number of branches (4.75) was produced by Week 6; these values were significantly different from each other. The results for number of leaves per plant showed that there is significant difference $(p<0.05)$ among the Weeks. The highest number of leaves (83.25) was recorded in Week 3; this value was statistically different from other Weeks. The lowest number of leaves (19.00) was recorded in Week 6.

The result obtained for the yield parameters of NDAGBACHI/MKW/2017 is presented in table 3 . The highest weight of fruit $(0.80)$ was recorded in the landrace transplanted at Week 5 after planting while the lowest $(0.38)$ was recorded in the landrace transplanted at Week 6 after planting. These values are significantly different from each other. In terms of number of fruits/plant, Week 3 had the highest number of fruits (27.50) per plant but was not significantly different $(\mathrm{p}>0.05)$ from those obtained in week 4 transplants. However, Week 6 produced the lowest number of fruits/plant (2.75). These values were statistically the same with all other Weeks. For number of seeds/fruit, the result showed that week 3 transplants produced significantly highest number of seeds per fruit among all the other weeks. The highest number of seeds (41.20) was produced by Week 3 while the lowest number of seeds (30.20) was produced by Week 6. The weight of 100 seeds recorded highest in Week $5(0.41 \mathrm{~g})$ and lowest in Week $6(0.20 \mathrm{~g})$; these values were significantly different $(\mathrm{p}<0.05)$ from each other and those of other weeks.

The result obtained for the yield parameters of NDAGBACHI/MKW/2017 is also presented in table 3. The Analysis of Variance for the weight of fruits showed that there is no significant difference ( $>0.05$ ) among the Weeks. However, the highest weight of fruit $(12.09 \mathrm{~g})$ was produced by Week 3 and the lowest weight of fruit $(7.97 \mathrm{~g})$ was recorded in Week 6. These values were not significantly different $(p>0.05)$ from all the other Weeks. In terms of number of fruits/plant, Week 4 had the highest number of fruits (35.00) per plant and was significantly different $(\mathrm{p}<0.05)$ from other Weeks. However, Week 6 produced the lowest number of fruits/plant (7.50). These values were statistically different $(\mathrm{p}<0.05)$ from other Weeks.

For number of seeds/fruit, the result showed that there is no significant difference ( $>0.05$ ) among the Weeks. The highest number of seeds (143.00) was produced by Week 3 while the lowest number of seeds (108.80) was produced by Week 5 . These values were significantly different from each other. For weight of 100 seeds, the ANOVA showed that there is highly significant difference $(p<0.05)$ between the Weeks. The highest weight $(0.52$ g) was produced by Week 3 while the lowest weight $(0.40 \mathrm{~g})$ was produced by Week 4 . The values were significantly different from one another (Table 3 ). 
The results obtained in terms of morphological and yield parameters in both pepper landraces (SOMBO/MKW/2017 and NDAGBACHI/MKW/2017) indicate that they were affected by various ages of transplants, this assertion is in line with that of AKINROTIMI \& ANIEKWE (2018). However, the result is in contrary from that of VAVRINA \& ARMBRESTER (2004) who found no effect of transplant age on yield (number and weight) in three of four harvests, but a significant yield increases at fourth harvest. The observed results in term of certain agro-morphological traits are in accordance with the report of SAFINA \& al. (2006) who reported that 40 days (5 weeks) old transplants recorded the highest plant height, 50 days (6 weeks) old transplants exhibited best growth in terms of number of branches and number of leaves per plant. The results obtained in terms of plant height at transplanting indicate that plant height varies with age. The results obtained for plant height at maturity show that 3 week old transplants produced the highest plant height for NDAGBACHI/MKW/2017 and the 4 week old transplants produced the highest plant height for SOMBO/MKW/2017. For plant height at harvest, 4 week old transplants recorded the highest plant heights in both landraces. This result is contrary to that of SAFINA \& al. (2006) who reported that 5 week old transplants recorded the highest plant height. This variation might be due to the differences in environmental factors and/or differences in growing seasons and even genetic factors. For number of branches per plant, 4 week old transplants produced the highest number of branches in both landraces. NORMAN (1977) who recommended 5-6 weeks old transplants for hot pepper production is in contrast to this finding, because 3 weeks old (for NDAGBACHI/MKW/2017) and 4 weeks old (for SOMBO/MKW/2017) transplants tend to perform better. These differences could be due to differences in environmental factors. For number of leaves, 3 weeks old transplants recorded the highest number in both landraces; this is in conformity with that reported by AKINROTIMI \& ANIEKWE (2018).

The results obtained for weight of fruits and weight of seeds indicate that landraces transplanted at 3 weeks after planting (for SOMBO/MKW/2017) and 5 week after planting (for NDAGBACHI/MKW/2017) produced the highest weight of fruits and seeds. The younger transplants (week 3 transplants) in this study produced the highest number of seeds per fruit. The results obtained for number of fruits per plant is an indication that 3 week old (for NDAGBACHI/MKW/2017) and 4 week old (for SOMBO/MKW/2017) transplants produced the highest number of fruits. This observation is in line with the work of SHUKLA \& al. (2011) who reported that middle aged transplants produced more number of fruits than the younger and older transplants. ADELANA (1983) also recommended that 3 and 4 weeks old transplants are the best for high yield of fruit of pepper (a Solanaceous plant). AKINROTIMI \& ANIEKWE (2018) opined that transplanting green pepper from 1 to 3 weeks was suitable transplanting time, because during this stage, the plant can easily withstand shock due to transplanting, without shedding its leaf. The possible reason seems to be that in case of younger seedlings there was less storage of food needed for vegetative extension, whereas, older transplants were mature enough and restrained vegetative extensions, thus producing lower yields. 
Table 1. Description of the Pepper (Capsicum spp.) genotypes used in this study.

\begin{tabular}{|l|l|l|l|l|}
\hline \multicolumn{1}{|c|}{ Landrace number } & Source & $\begin{array}{c}\text { Local } \\
\text { name }\end{array}$ & $\begin{array}{c}\text { Botanical } \\
\text { name }\end{array}$ & \multicolumn{1}{c|}{ Botanical description } \\
\hline SOMBO/MKW/2017 & Mokwa & Sombo & $\begin{array}{l}\text { Capsicum } \\
\text { annuum }\end{array}$ & $\begin{array}{l}\text { Medium-sized annual plant, long } \\
\text { pointed and pendant fruits with hot } \\
\text { taste, one pedicel per node. }\end{array}$ \\
\hline NDAGBACHI/MKW/2017 & Mokwa & Ndagbachi & $\begin{array}{l}\text { Capsicum } \\
\text { frutescens }\end{array}$ & $\begin{array}{l}\text { A small-sized perennial plant, with } \\
\text { very hot taste, three to five pedicels } \\
\text { per node. }\end{array}$ \\
\hline
\end{tabular}

Table 2. Morphological parameters of the selected landraces of Capsicum spp.

\begin{tabular}{|l|l|l|l|l|l|}
\hline \multirow{2}{*}{$\begin{array}{c}\text { Age at } \\
\text { transplant }\end{array}$} & \multicolumn{3}{|c|}{ Height/cm } & \multicolumn{2}{c|}{ Morphology at maturity } \\
\cline { 2 - 6 } & Transplanting & Maturity & Harvest & $\begin{array}{c}\text { Number of } \\
\text { branches }\end{array}$ & $\begin{array}{c}\text { Number of } \\
\text { leaves }\end{array}$ \\
\hline \multicolumn{7}{|c|}{ NDAGBACHI/MKW/2017 } \\
\hline Week 3 & $4.05 \pm 0.05^{\mathrm{a}}$ & $33.00 \pm 4.00^{\mathrm{b}}$ & $33.75 \pm 1.25^{\mathrm{a}}$ & $5.25 \pm 2.25^{\mathrm{b}}$ & $39.50 \pm 4.50^{\mathrm{b}}$ \\
\hline Week 4 & $4.18 \pm 0.33^{\mathrm{b}}$ & $23.00 \pm 2.00^{\mathrm{a}}$ & $37.75 \pm 0.75^{\mathrm{b}}$ & $8.00 \pm 1.00^{\mathrm{b}}$ & $33.00 \pm 1.50^{\mathrm{b}}$ \\
\hline Week 5 & $6.00 \pm 0.50^{\mathrm{b}}$ & $29.75 \pm 6.25^{\mathrm{ab}}$ & $32.05 \pm 8.45^{\mathrm{a}}$ & $5.25 \pm 1.75^{\mathrm{b}}$ & $38.25 \pm 6.75^{\mathrm{b}}$ \\
\hline Week 6 & $6.50 \pm 0.75^{\mathrm{c}}$ & $23.13 \pm 3.88^{\mathrm{a}}$ & $27.13 \pm 3.03^{\mathrm{a}}$ & $2.75 \pm 0.25^{\mathrm{a}}$ & $19.25 \pm 6.25^{\mathrm{a}}$ \\
\hline Total & $5.18 \pm 0.45$ & $27.22 \pm 2.30$ & $32.67 \pm 2.24$ & $5.31 \pm 0.91$ & $32.50 \pm 3.61$ \\
\hline \multicolumn{7}{|c|}{ SOMBO/MKW/2017 } & \\
\hline Week 3 & $3.80 \pm 0.50^{\mathrm{a}}$ & $21.38 \pm 0.13^{\mathrm{c}}$ & $28.25 \pm 4.75^{\mathrm{b}}$ & $6.50 \pm 0.50^{\mathrm{ab}}$ & $83.25 \pm 11.75^{\mathrm{c}}$ \\
\hline Week 4 & $4.35 \pm 0.00^{\mathrm{b}}$ & $30.08 \pm 7.93^{\mathrm{d}}$ & $32.50 \pm 7.50^{\mathrm{b}}$ & $9.25 \pm 0.25^{\mathrm{c}}$ & $60.50 \pm 3.00^{\mathrm{b}}$ \\
\hline Week 5 & $4.53 \pm 0.73^{\mathrm{c}}$ & $17.13 \pm 0.88^{\mathrm{b}}$ & $24.25 \pm 0.75^{\mathrm{b}}$ & $7.25 \pm 0.75^{\mathrm{b}}$ & $64.00 \pm 4.00^{\mathrm{b}}$ \\
\hline Week 6 & $3.95 \pm 0.5^{\mathrm{d}}$ & $8.38 \pm 0.13^{\mathrm{a}}$ & $21.00 \pm 1.00^{\mathrm{a}}$ & $4.75 \pm 0.25^{\mathrm{a}}$ & $19.00 \pm 2.00^{\mathrm{a}}$ \\
\hline Total & $4.16 \pm 0.20$ & $19.24 \pm 3.22$ & $26.50 \pm 2.35$ & $6.94 \pm 0.64$ & $56.69 \pm 5.19$ \\
\hline
\end{tabular}

Values are means \pm standard error, values followed by the same superscript on the same column is not significantly different at $\mathrm{p}>0.05$ tested by DMRT.

Table 3. Yield parameters of the selected landraces of Capsicum sp.

\begin{tabular}{|l|l|l|l|l|}
\hline $\begin{array}{c}\text { Age at } \\
\text { transplant }\end{array}$ & \multicolumn{1}{|c|}{$\begin{array}{c}\text { Number of } \\
\text { fruits/plant }\end{array}$} & $\begin{array}{c}\text { Weight of fruits } \\
\text { (g) }\end{array}$ & \multicolumn{1}{|c|}{$\begin{array}{c}\text { Number of } \\
\text { seeds/fruit }\end{array}$} & $\begin{array}{c}\text { Weight of 100 } \\
\text { seeds (g) }\end{array}$ \\
\hline \multicolumn{5}{|c|}{ NDAGBACHI/MKW/2017 } \\
\hline Week 3 & $27.50 \pm 2.00^{\mathrm{c}}$ & $0.56 \pm 0.07^{\mathrm{b}}$ & $41.20 \pm 1.85^{\mathrm{b}}$ & $0.25 \pm 0.00^{\mathrm{b}}$ \\
\hline Week 4 & $23.75 \pm 2.25^{\mathrm{c}}$ & $0.77 \pm 0.04^{\mathrm{c}}$ & $37.40 \pm 2.68^{\mathrm{ab}}$ & $0.38 \pm 0.00^{\mathrm{c}}$ \\
\hline Week 5 & $17.50 \pm 3.00^{\mathrm{b}}$ & $0.80 \pm 0.06^{\mathrm{c}}$ & $37.80 \pm 5.18^{\mathrm{ab}}$ & $0.41 \pm 0.00^{\mathrm{d}}$ \\
\hline Week 6 & $13.75 \pm 0.75^{\mathrm{a}}$ & $0.38 \pm 0.06^{\mathrm{a}}$ & $30.20 \pm 4.50^{\mathrm{a}}$ & $0.20 \pm 0.00^{\mathrm{a}}$ \\
\hline Total & $20.63 \pm 0.91$ & $0.63 \pm 0.05$ & $36.65 \pm 1.97$ & $0.31 \pm 0.20$ \\
\hline \multicolumn{5}{|c|}{ SOMBO/MKW/2017 } \\
\hline Week 3 & $11.25 \pm 0.75^{\mathrm{b}}$ & $12.09 \pm 2.06^{\mathrm{a}}$ & $143.00 \pm 11.47^{\mathrm{b}}$ & $0.52 \pm 0.00^{\mathrm{d}}$ \\
\hline Week 4 & $35.00 \pm 2.50^{\mathrm{d}}$ & $8.91 \pm 1.65^{\mathrm{a}}$ & $127.40 \pm 18.76^{\mathrm{b}}$ & $0.40 \pm 0.00^{\mathrm{a}}$ \\
\hline Week 5 & $25.00 \pm 1.50^{\mathrm{c}}$ & $8.51 \pm 1.26^{\mathrm{a}}$ & $108.80 \pm 21.40^{\mathrm{a}}$ & $0.42 \pm 0.00^{\mathrm{c}}$ \\
\hline Week 6 & $7.50 \pm 0.50^{\mathrm{a}}$ & $7.97 \pm 1.75^{\mathrm{a}}$ & $115.40 \pm 14.55^{\mathrm{a}}$ & $0.41 \pm 0.00^{\mathrm{b}}$ \\
\hline Total & $19.69 \pm 0.01$ & $9.37 \pm 0.86$ & $123.65 \pm 8.34$ & $0.44 \pm 0.00$ \\
\hline
\end{tabular}

Values are means \pm standard error, values followed by the same superscript on the same column is not significantly different at $\mathrm{p}>0.05$ tested by DMRT. 


\section{Conclusion and recommendation}

It can be concluded that Although, different transplanting ages tend to favour different agro-morphological traits, the best ages for transplanting of both the pepper landraces SOMBO/MKW/2017 and NDAGBACHI/MKW/2017) for optimum yield attribute preferred by growers (number of fruits per plant) are the 3-4 week after planting. Also, more specifically, 3 and 4 week old transplants seem to be the best age to produce more yields for NDAGBACHI/MKW/2017 and SOMBO/MKW/2017 respectively. It is therefore recommended that appropriate timing for transplanting, as an important cultural practice, should be considered for optimum production of the selected pepper landraces in Niger State, Nigeria.

\section{Notes on contributors}

Oladipupo Abdulazeez Yusuf DAUDU - is a Plant breeder with special interest in germplasm studies of indigenous crop plants. He holds a $\mathrm{PhD}$ in applied plant genetics and breeding.

Olamide Ahmed FALUSI - is a professor of plant cytogenetics and breeding with special interest in inheritance studies of plants.

Abdulhakeem ABUBAKAR - is Plant geneticist and breeder with special interest in mutation breeding. He holds a $\mathrm{PhD}$ in applied plant genetics and breeding.

Aishatu Adamu GADO - is a plant biologist with a special in plant genetics and germplasm studies. She holds a PhD in applied plant genetics and breeding.

Emmanuel Junior NWELIH - He is a Masters Student in applied plant genetics and breeding.

\section{References}

AKINROTIMI C. A. \& ANIEKWE N. L. 2018. Effect of transplanting age on the growth and yield of Green Pepper (Capsicum annuum L.) in Abakaliki Southeastern Agro-Ecological zone of Nigeria. Agricultural Extension Journal. 2(2): 106-110. SSRN: https://ssrn.com/abstract=3662966.

ADELANA B. O. 1983. Effect of age of transplant on the growth and yield of tomato. Acta Horticulturae. 123(5): 207-216.https://doi.org/10.17660/ActaHortic.1983.123.18

AKINYELE B. O. \& OSEKITA O. S. 2006. Correlation and path coefficient analysis of seed yield attributes in Okra (Abelmoschus esculentus). African Journal of Biotechnology. 5(14): 1330-1336. https://doi.org/10.5897/AJB2006.000-5064.

BOSLAND P. W. \& VOTAVA E. J. 2012. Peppers: Vegetable and spice Capsicums. ATHERTON J. \& REES A. (eds.), Oxford, CABI Publishing, pp. 199.

COSTA L. V., LOPES R., LOPES M. T. G., DE FIGUEIREDO A. F., BARROS W. S. \& ALVES S. R. M. 2009. Cross compatibility of domesticated hot pepper and cultivated sweet pepper. Crop Breeding and Applied Biotechnology. 9: 37-44.

DAGNOKO S., YARO-DIARISSO N., SANOGO P. N., ADETULA O., DOLO-NANTOUME A., GAMBYTOURE K., TRAORE-THERA A., KATILE S. \& DIALLO-BA D. 2013. Overview of pepper (Capsicum spp.) breeding in West Africa. African Journal of Agricultural Research. 8(13): 1108-1114. https://doi.org/10.5897/AJAR2012.1758

FALUSI O. A. \& MORAKINYO J. A. 2001. Pollen and hybridization studies in some Nigerian species of peppers. Nigerian Journal Technology and Education. 1\&2: 40-43.

FALUSI O. A. 2007. Germplasm collection of peppers (Capsicum spp.) in Nigeria. Research on Crops. 8: 765768.

DAUDU O. A. Y., FALUSI O. A., DANGANA M. C., ABUBAKAR A., YAHAYA S. A. \& ABEJIDE D. R. 2015. Collection and evaluation of Roselle (Hibiscus sabdariffa L.) germplasm in Nigeria. African Journal of Food Science. 9(3): 92-96. https://doi.org/10.5897/AJFS2014.1225

GREENLEAF W. H. 1986. Pepper Breeding. In: BASSETT M. J. (ed.), Breeding Vegetable Crops. USA, AVI Publishing Co Inc., pp. 67-134. 
GRUBBEN G. J. H. \& EL-TAHIR I. M. 2004. Capsicum annuum L. In: GRUBBEN G. J. H. \& DENTON O. A. (eds.). PROTA 2: Vegetables/Légumes. PROTA. Wageningen, the Netherlands, pp. 154-163.

HILL T. A., ASHRAFI H., REYES-CHIN-WO S., YAO J., STOFFEL K., TRUCO M. A., KOZIK A., MICHELMORE R. W. \& DEYNZE A. V. 2013. Characterization of Capsicum annuum genetic diversity and population structure based on parallel polymorphism discovery with a $30 \mathrm{~K}$ Unigene Pepper GeneChip. Plos One. 8(2): 1-16. https://doi.org/10.1371/journal.pone0056200

KUMAR S. \& RAI M. 2005. Chile in India. Chile Pepper Institute Newsletter. 22: 1-3.

LEE J. W., KIM K. Y. \& YU Y. M. 2001. Effect of nutrient solution, strength, seedling age and container size on seedling quality and yield of 'Spirit' coloured bell pepper (Capsicum annuum L.). Journal of the Korean Society for Horticultural Science. 42(3): 300-304.

LESKOVAR D. I., CANTLIFFE D. J. \& STOFFELLA P. J. 1991. Growth and yield of tomato plants in response to age of transplants. Journal of the American Society for Horticultural Science. 116(3): 416-420. https://doi.org/10.21273/JASHS.116.3.416

LIPTAY A. 1987. Field survival and establishment of tomato transplants of various age and size. Acta Horticulturae. 220: 203-209.

MADY E. A., UGURU M. I. \& UGWOKE K. I. 2005. Interrelations of growth and disease expression in pepper using principal component analysis. Proceedings of the $30^{\text {th }}$ Annual National Conference of Genetic Society of Nigeria. pp. 55-59.

MCCRAW B. D. \& GREIG J. K.1986. Effect of transplant age and pruning procedure on yield and fruit set of bell pepper. Horticultural Science. 21(3): 430-431.

NORMAN J. C. 1977. Effect of age of transplants on hot pepper (Capsicum chinense L.). Acta Horticulturae. 53: 43-48. https://doi.org/10.17660/ActaHortic.1977.53.3

ORZOLEK M. D., VAVRINA C. S. \& SCOTT R. 1991. Tomato transplant age study. Vegetable Research Report Horticultural Mimeo. II: 195.

PICKERSGILL B. 1997. Genetic resources and breeding of Capsicum spp. Euphytica. 96: 129-133. https://doi.org/10.1023/A:1002913228101

SAFINA N., MUHAMMAD A. A. \& ISHTIAQ A. 2006. Growth of chilli pepper (Capsicum annuum L.) F1 hybrid sky line-2 in response to different ages of transplants. Journal of Research (Science) Bahauddin Zakariya University, Multan, Pakistan. 17(2): 91-95.

SHETTY A. A., MAGADUM S. \& MANAGANVI K. 2013. Vegetables as sources of antioxidants. Journal of Food \& Nutritional Disorders. 2(1): 1-5. https://doi.org/10.4172/2324-9323.1000104

SHUKLA Y. R., CHHOPAL T. \& SHARMA R. 2011. Effect of age of transplants on growth and yield of Capsicum. International Journal of Farm Sciences. 1(2): 56-62. Corpus ID: 73199351

SUNDSTROM F. J., THOMAS C. H., EDWARDS R. L. \& BASKINS G. R. 1994. Influence of N and plant spacing on mechanically harvested Tabasco peppers. Journal of the American Society for Horticultural Science. 109: 642-645.

VASCONCELOS C. S. 2016. Recursos genéticos de pimentas (Capsicum, Solanaceae): qualidade de frutos após a colheita e ação dos compostos antioxidantes na prevenção da síndrome metabólica. PhD Thesis, Universidade Federal de Pelotas - RS, Brazil.

VAVRINA C. S. 1998. Transplant Age in Vegetable Crops. Horticultural Technology. 8(4): 1-7. https://doi.org/10.21273/HORTTECH.8.4.550

VAVRINA C. S. \& ARMBRESTER K. 2004. Effects of transplant age and cell size on pepper production. SWFREC Research Report IMM. 12: 91-8.

WESTON L. A. 1988. Effect of flat cell size, transplant age and production site on growth and yield of pepper transplants. Horticultural Science. 22(4): 709-711.

How to cite this article:

DAUDU O. A. Y., FALUSI O. A., ABUBAKAR A., GADO A. A. \& NWELIH E. J. 2020. Variation in ages of transplants affects agro-morphological traits of selected pepper landraces from Niger State, Nigeria. J. Plant Develop. 27: 103-110. https://doi.org/10.33628/jpd.2020.27.1.103 